\title{
Detecting Gender Discrimination in University Salaries: A Case Study ${ }^{*}$
}

\section{LEORA C. SWARTZMAN, CLIVE SELIGMAN, \& WILLIAM J. MCCLELLAND ${ }^{\dagger}$}

\begin{abstract}
To assess sex discrimination in university salary allocation accurately, one must determine whether gender explains the salary difference in and of itself, or exerts its influence through other variables, such as rank and departmental affiliation, that themselves affect salary and may correlate with gender. Using members of the Faculty of Social Science ( $\underline{N}=133)$ of a large Canadian university as a case sample, we assessed gender discrimination in promotion and gender differences in departmental affiliation as related to salary before including these two variables in statistical analyses predicting salary. No evidence was found for discrimination in promotion and women were not more under-represented in the higher-salaried departments. Several regression models recommended in the literature for assessing gender discrimination in salaries were conducted and yielded convergent findings: male and female faculty similar on salary-relevant variables were equivalently paid. While these results should be reassuring, they would not go very far toward resolving salary discrimination disputes in the university studied or in most other academic institutions. The difficulties of applying the results of statistical analyses within a politically-charged arena are discussed.
\end{abstract}

\section{Résumé}

Afin d'évaluer avec précision le degré de discrimination sexuelle dans l'allocation des salaires universitaires, on doit déterminer si le sexe en soi

* The authors would like to thank Tom Sea, former acting Dean of Social Science at the University of Western Ontario and Emöke Szathmary, Dean of Social Science at the University of Western Ontario for their assistance. We are also grateful to Manon Houle for translating the abstract into French.

$\dagger$ University of Western Ontario, Department of Psychology 
explique la différence salariale ou s'il exerce son influence par l'intermédiaire d'autres variables, telles le rang et les affiliations départementales, qui influencent elles-mêmes les salaires et qui pourraient être en corrélation avec le sexe. Prenant comme échantillon représentatif le corps professoral de la faculté des sciences sociales $(\underline{N}=133)$ d'une grande université canadienne, on a évalué la discrimination sexuelle dans l'avancement et les différences sexuelles dans les affiliations départementales se rapportant aux salaires avant d'inclure ces deux variables dans les analyses statistiques pouvant predire les salaires. On n'apporte aucun appui à l' existence de discrimination dans l'avancement et le nombre de femmes affiliées aux départements dont les salaires sont plus élevés n'est pas inférieur. Plusieurs modèles de régression recommandés dans la documentation concernant l'évaluation de la discrimination sexuelle ont été effectués et ont produit des résultats convergents: qu'il s'agisse d'hommes ou de femmes, les professeurs qui correspondaient de façon semblable aux variables se rapportant aux salaires étaient rémunérés de façon égale. Tandis que ces résultats devaient être rassurants, on observe qu'ils n'aideront pas beaucoup à résoudre les disputes sur la discrimination salariale dans la plupart des institutions académiques y compris la nôtre. Sont abordées les difficultés d'appliquer les résultats d'analyses statistiques dans un milieu très politisé.

Over the past two decades, concern about sex discrimination within institutions of higher education has increased (Kahn \& Robbins, 1985). The focus of most research on sex discrimination in academe has been on salary allocation (e.g., Pezzullo \& Brittingham, 1979; Schau \& Heyward, 1987; Schrank, 1977, 1985). The analyses consistently show that female faculty earn approximately 82 percent to 88 percent of what males earn. Moreover, there is little indication that this gap has diminished appreciably over time. For example, in 1975, the median salary of all Canadian full-time female academics was 82 percent that of men; in 1985, females earned 81 percent of what males earned (Hollands, 1988).

The finding of gender differences in average salaries is not evidence itself of sex discrimination in this realm. To assess sex discrimination in salary allocation accurately, one must determine whether gender explains the salary difference in and of itself, or whether it exerts its influence through other variables that themselves affect salary and correlate with gender. Typically, gender bias is said to exist (e.g., Morse, 1979) if gender accounts for a significant proportion of the variance in salary after the effects of other 
variables have been statistically controlled. Considerable attention has been directed at how best to accomplish this statistical control (e.g., Carter, Das, Garnello, \& Charboneau, 1984; Johnson, Riggs, \& Downey, 1987; McLaughlin, Zirkes, \& Mahan, 1983; Pezzullo \& Brittingham, 1979; Schau \& Heyward, 1987; Shrank, 1977).

Initially, linear regression was widely used to detect gender bias in salary allocation (e.g., Lassiter, 1983; Morse, 1979). In this data analytic approach, salary is the criterion variable and those variables expected to influence salary are the predictors. Gender, coded as a dummy variable, is entered into the equation last. The variance in salary accounted for by gender after all other variables have been entered into the regression provides an estimate of gender bias. Furthermore, examining the actual versus predicted salaries (the latter based on a regression equation derived from all predictors except gender) of males and females yields a dollar value estimate of how much females are under or over-compensated relative to their male colleagues.

In more recent years, concerns have been raised about this approach, and, in response, variations in the regression approach have been considered. For example, it has been shown (Johnson et al., 1987; Schau \& Heyward, 1987) that one's estimate of gender bias is influenced by whether the prediction equation is based on the data of all faculty (as is typically the case) or is based on the data of only male faculty. Conceptually, the latter approach seems to provide a better gauge of salary equity; it enables one to assess whether female faculty, who are equivalent to their male colleagues on all salary relevant variables and equivalent with respect to the monetary value of each variable unit, are paid more or less than predicted by the male-derived equation.

Another concern voiced repeatedly over the past several years (Johnson et al., 1987; McLaughlin et al., 1983; Schau \& Heyward, 1987) is how to interpret regression weights when gender and other predictors are intercorrelated (i.e., muticollinearity) and how best to control statistically for this correlation. The issue centres around the presumed reason for the correlation between gender and the other predictor variables. Using rank as an example: if men and women are equally likely to be promoted (i.e., there is no discrimination in promotion), then arguably, rank is a useful predictor. This is because removing the effects of rank on salary controls for the possible unequal distribution of men and women at the various ranks. If, however, male faculty are unfairly advantaged in promotions, then rank is a "tainted" (i.e., sex-biased) predictor, and its inclusion in the regression equation will underestimate the salary bias against women because it accounts for some of the variability in salary that otherwise would be associated with gender. 
Another predictor that may correlate with both salary and gender is departmental affiliation. There is at least circumstantial evidence that this may be the case. First, there are recognized salary differences across disciplines (Tuckman, 1979). Second, there is considerable variability in the proportion of women across disciplines. This, then, raises the question of whether departmental affiliation is a useful or misleading predictor of salaries. If various disciplines are paid differently because of market conditions, it would be proper to include department as a predictor of salary. If, however, academic work done by women is devalued (as suggested by Lott, 1985), then part of the difference in salary between a male-dominated department and a female-dominated one is due to prejudice and discrimination; this would be masked in the regression model that includes department as a predictor.

Accordingly, in the case study we present below, using data from one faculty in one university, we first assessed gender discrimination in promotion and gender differences in departmental affiliation as they relate to salary. We then tested for gender discrimination in salary using multiple regression analyses as described earlier.

\section{Method}

\section{Subjects}

The sample consisted of all assistant and associate professors in the Faculty of Social Science at the University. of Western Ontario in 1988/89. The Faculty is composed of seven departments and one centre. Of the 133 faculty, 107 (80.5 percent) were male and 26 (19.5 percent)were female. The mean $(\underline{\mathrm{M}})$, median (MDN), and standard deviation (SD) for the variables of interest are presented (by rank and gender) in Table 1. Full professors were excluded from the study because female faculty at this rank were too limited in number (i.e., $\underline{\mathbf{n}}=2$ ).

\section{Procedure}

Data for each faculty member were coded by the Associate Dean. To preserve confidentiality, individual faculty were assigned subject numbers and data were entered and analysed by personnel in the Social Science computer laboratory. Moreover, only personnel in the Dean's office and the computer laboratory had access to the raw data.

The variables included in the analyses were: 1) salary, 2) gender, 3) age, 4) rank, 5) years in rank, 6) highest degree earned, 7) years since highest degree earned, 8) years since first appointed as assistant professor at any institution, and 9) average salary of individual's department. 
Table 1

Means, Medians and Standard Deviations of Several Salary Predictors by Gender and Professorial Rank

\begin{tabular}{|c|c|c|c|c|}
\hline & \multirow{4}{*}{ Age } & & $\underline{\text { Males }}$ & $\underline{\text { Females }}$ \\
\hline & & $\underline{\mathrm{M}}$ & 35.90 & 36.94 \\
\hline & & $\underline{\text { MDN }}$ & 36 & 34 \\
\hline & & $\underline{\mathrm{SD}}$ & 5.13 & 6.57 \\
\hline & \multirow{3}{*}{$\begin{array}{l}\text { Years since first } \\
\text { appointed as } \\
\text { assistant professor }\end{array}$} & $\underline{\mathrm{M}}$ & 5.00 & 4.81 \\
\hline & & $\underline{\mathrm{MDN}}$ & 4 & 3 \\
\hline & & $\underline{\mathrm{SD}}$ & 3.65 & 4.85 \\
\hline & \multirow{3}{*}{$\begin{array}{l}\text { Years since } \\
\text { highest degree }\end{array}$} & $\underline{\mathrm{M}}$ & 5.09 & 5.06 \\
\hline & & $\underline{\mathrm{MDN}}$ & 4 & 3 \\
\hline & & $\underline{\mathrm{SD}}$ & 3.32 & 4.30 \\
\hline \multirow{10}{*}{$\begin{array}{l}\text { Assistant } \\
\text { Professors }\end{array}$} & \multirow{3}{*}{$\begin{array}{l}\text { Years in } \\
\text { current rank }\end{array}$} & $\underline{\mathrm{M}}$ & 3.24 & 3.00 \\
\hline & & $\underline{\mathrm{MDN}}$ & 2 & 2 \\
\hline & & $\underline{\mathrm{SD}}$ & 3.06 & 2.66 \\
\hline & \multicolumn{2}{|l|}{ Sample Size } & 33 & 16 \\
\hline & \multirow[t]{3}{*}{ Age } & $\underline{\mathrm{M}}$ & 44.27 & 47.50 \\
\hline & & $\underline{\mathrm{MDN}}$ & 42 & 46 \\
\hline & & $\underline{\mathrm{SD}}$ & 8.36 & 7.10 \\
\hline & \multirow{3}{*}{$\begin{array}{l}\text { Years since first } \\
\text { appointed as } \\
\text { assistant professor }\end{array}$} & $\underline{\mathrm{M}}$ & 14.20 & 12.60 \\
\hline & & $\underline{\text { MDN }}$ & 12 & 10.5 \\
\hline & & $\underline{\mathrm{SD}}$ & 6.88 & 7.52 \\
\hline \multirow{7}{*}{$\begin{array}{l}\text { Associate } \\
\text { Professors }\end{array}$} & \multirow{3}{*}{$\begin{array}{l}\text { Years since } \\
\text { highest degree }\end{array}$} & $\underline{\mathbf{M}}$ & 14.78 & 13.60 \\
\hline & & $\mathrm{MDN}$ & 13.5 & 11 \\
\hline & & $\underline{\mathrm{SD}}$ & 7.67 & 7.43 \\
\hline & \multirow{3}{*}{$\begin{array}{l}\text { Years in } \\
\text { current rank }\end{array}$} & $\underline{\mathrm{M}}$ & 8.24 & 5.60 \\
\hline & & $\underline{\mathrm{MDN}}$ & 6 & 4 \\
\hline & & $\underline{\mathrm{SD}}$ & 6.76 & 5.25 \\
\hline & \multicolumn{2}{|l|}{ Sample Size } & 74 & 10 \\
\hline
\end{tabular}


Ideally, we would have liked to have included merit or other ratings of performance. However, because of the difficulty in obtaining valid measures of performance, especially across departments, we did not include this variable.

\section{Results}

\section{Gender Discrimination in Promotion}

A discriminant function analysis to predict rank (assistant versus associate professors) was conducted using the following predictors: age, highest degree, years since highest degree, years since first appointed as assistant professor, and average salary of department. The discriminant analysis correctly classified 84.2 percent (112 of 133) of the faculty. Of the 26 women faculty, 21 ( 80.8 percent) were classified correctly, three ( 11.5 percent) were underpredicted, and two $(7.7$ percent) overpredicted. Of the 107 men, 91 ( 85 percent) were correctly classified, twelve men (13.2 percent) were underpredicted, and four (4.4 percent) were over predicted. According to a chi-square analysis, men and women were equally likely to be correctly classified, $x^{2}(1)=.63$, ns. Moreover, of those incorrectly classified, men were not more likely to be overpredicted than women, $\mathrm{x}^{2}(1)=1.72, \underline{\mathrm{ns}}^{1}$.

One can further test the hypothesis that women are unfairly held back in rank, compared to men, by examining data presented in Table 1. To make the argument that women are being discriminated against, one would first have to show that women, on average, have been in rank longer than males and have had their Ph.D.'s longer than males. The data, however, indicate that male and female assistant professors, on average, have been in rank and have had their Ph.D.'s almost identical amounts of time. At the associate level, the results show that men have been in rank and have had their Ph.D.'s longer than women, a finding which is inconsistent with the hypothesis.

We thus conclude that neither the discriminant analysis nor the data in Table 1 suggest that female faculty are treated differently than male faculty in promotion decisions.

\section{Gender and Departmental Salary}

To examine the possibility that women are under-represented in the higher paid departments, the correlations between gender $(0=$ female, $1=$ male $)$ and average departmental salary was calculated. The correlation $(\underline{r}=.13, \underline{N}=133)$ is not statistically significant. Moreover, the correlation between average 
department salary and the proportion of male faculty in a department also is not statistically significant ( $\underline{r}=.19, \underline{\mathbf{N}}=8$ academic units in the faculty). Thus, the data do not suggest that women are concentrated in the lower-paying departments, at least for our sample.

\section{Gender Discrimination in Salary Allocation}

Next, a forward stepwise multiple regression analysis predicting salary was conducted. The model accounted for 76 percent of the variance in salary, $\underline{F}(8,124)=49.5, \underline{p}<.0001$ (see Table 2). Gender did not account for a significant enough portion of variance even to be entered into the model. Furthermore, in a multiple regression in which the variables were entered simultaneously, gender accounted for a statistically nonsignificant amount of the variance (i.e., less than .001 percent) in salary.

Table 2

\section{Forward Stepwise Regression Predicting Salary}

\begin{tabular}{|c|c|c|c|c|}
\hline Variable & Step & $\underline{F}$ & $\begin{array}{l}\text { Incremental } \\
\text { Variance }\left(\underline{\underline{r}}^{2}\right)\end{array}$ & $\begin{array}{l}\text { Cumulative Variance } \\
\qquad\left(\operatorname{Model} \underline{r}^{2}\right)^{\mathrm{a}}\end{array}$ \\
\hline $\begin{array}{l}\text { Years since first } \\
\text { appointed as } \\
\text { assistant professor }\end{array}$ & 1 & 128.3 & $.495 * * *$ & .495 \\
\hline $\begin{array}{l}\text { Average salary } \\
\text { of department }\end{array}$ & 2 & 54.2 & $.143 * * *$ & .638 \\
\hline Rank & 3 & 41.7 & $.089 * * *$ & .726 \\
\hline $\begin{array}{l}\text { Years in } \\
\text { current rank }\end{array}$ & 4 & 12.5 & $.024 * *$ & .750 \\
\hline Highest Degree & 5 & 5.2 & $.010^{*}$ & .760 \\
\hline \multicolumn{5}{|c|}{ Note: None of the remaining variables explained additional variance } \\
\hline \multicolumn{5}{|c|}{ a The model $\underline{r}^{2}$ is significant at $\underline{p}<.0001$ at all five steps } \\
\hline
\end{tabular}


Another way of analyzing these data is through covariance analysis. A comparison of the uncorrected mean salaries reveals that female faculty earn 87 percent of what males earn, a statistically significant difference, $\underline{t}(131)=$ $2.85, \mathrm{p}<.006$. When the effects of all other predictor variables are covaried out, the salary differences disappear, $\underline{\mathrm{t}}(124)=.10$, $\underline{\mathrm{ns}}$, with women earning 99.7 percent of what males earn. Indeed, one need not include all predictors to reduce the mean difference in salaries (see Figure 1). Consider, in turn, only the three strongest predictors identified by the forward stepwise regression; after correcting for years since first appointed as an assistant professor, the female portion of male salary rises from 87 percent to 94 percent (and is only marginally statistically different, $\underline{\mathrm{t}}(130)=1.78, \mathrm{p}=.08)$. With a further correction for average salary of department, females earn 97.0 percent of what their male counterparts earn. This difference is not statistically significant, $t$ $(129)=1.01, \underline{\text { ns. }}$. With the additional correction for rank, the proportion increases to 99.7 percent, $\underline{\mathrm{t}}(128)<1$, $\underline{\mathrm{ns}}$.

Variables for which Salary is Adjusted ${ }^{1}$

Years since first
appointed as assistant
professor

${ }^{1}$ Salary is adjusted by covariance analyses

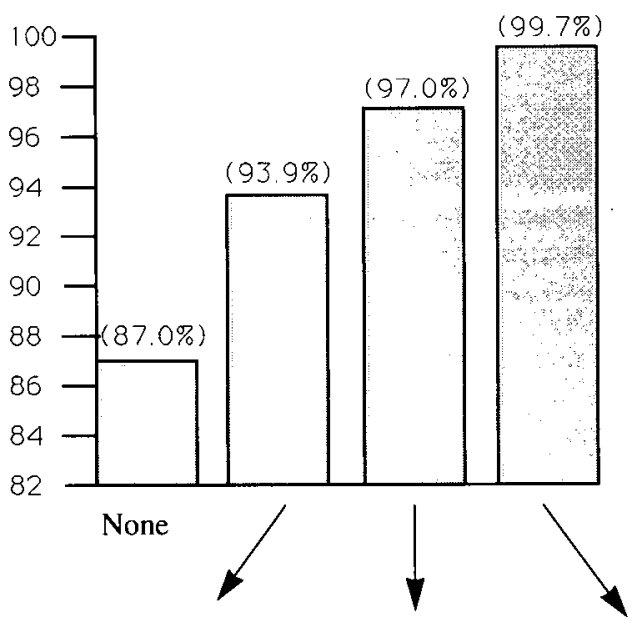

Years since first Years since appointed as first appointed assistant as assistant professor professor + Average + Average department salary department salary + Rank

Figure 1. Female salary as a proportion of male salary 
Therefore, on the basis of these analyses, one can conclude that, given the same rank, the same number of years since first appointed as assistant professor, and membership in the same department, female and male social science faculty are equivalently paid.

\section{Actual versus Predicted Salaries Based on "All Faculty" and "Male Only" Equations}

To corroborate these findings, two additional analyses were conducted. First, a multiple regression to predict salary was conducted on the entire sample, using all predictors except gender. Based on the regression equation, predicted salaries were determined for both males and females. The regression equation accounted for 76.2 percent of the variance in salaries, $\underline{F}(7,125)=$ $57.0, \mathrm{p}<.0001$. The difference between actual and predicted salary (i.e., actual salary minus predicted salary) for men was $\$ 21.84(\underline{\mathrm{SD}}=\$ 5877)$, which is not statistically different from zero, $\underline{\mathrm{t}}<1$. The difference between actual and predicted salary for women was $-\$ 89.91(\underline{\mathrm{SD}}=\$ 4356)$, which also is not significantly different from zero, $\underline{\mathrm{t}}<1$. As might be expected, the difference between male and female difference scores, $\$ 111.75$, was not statistically significant either, $\mathrm{t}<1$.

Second, a regression equation to predict salaries (using the same predictors as in the prior analysis) was then determined from the male sample. The equation accounted for 75.1 percent of the variability in men's salaries, $\underline{F}(7,75)$ $=58.0, \underline{\mathrm{p}}<.0001$. This equation was used to predict women's salaries. The average difference between women's actual and predicted salaries, $\$ 36.83$, is not statistically different from zero, $\underline{t}<1$. This finding is consistent with the analyses already presented.

\section{Discussion}

The results of our analyses do not provide any evidence of gender bias in salary allocation or in promotional practices in the Faculty of Social Science, at least at the assistant and associate professor levels. Men and women who are similar on important salary-relevant variables are equivalently paid. The regression analyses show that an equation based on the whole sample predicts salaries equally well for male and female faculty and an equation derived from the male sample alone also predicts female salaries well. Moreover, with respect to promotional practices, the discriminant analysis predicted male and female ranks with the same accuracy, and females' ranks were not more likely to be under or overpredicted than those of males. 
We should reiterate that an important variable omitted from our analyses was merit (i.e., the caliber of academic career performance). However, some have suggested (e.g., Schau \& Heyward, 1987; Scott, 1979) that merit ratings are unlikely to add very much to the explained variance in salary because variables that correlate with it, such as rank and years in rank, are already included in the regression equation. Moreover, one wonders whether any measure of merit applied across disciplines would receive wide agreement among professors.

In this investigation, gender discrimination in both salary and promotion was assessed separately. This approach (also see Ervin, Thomas, \& Zey-Ferrell, 1984) is worth emphasizing since much recent research has focussed explicitly on gender discrimination in salary allocation alone. The concentration on salary discrimination might have arisen because pay equity legislation has provided universities with a mandate for such analyses, or because salary is more easily studied (and possibly adjusted) than other academic rewards. Nevertheless, there are compelling reasons to assess gender discrimination in the allocation of non-monetary rewards ( such as promotion and type of appointment) explicitly; women are strikingly underrepresented in academe ( within the discipline of psychology, for example), at both senior ranks and entry level positions ( e.g., Emmons, 1982; Guttmann, 1985).

This unequal sex distribution has not changed much over the years, despite the fact that women have been comprising an increasing proportion of doctorate recipients (Syverson, 1982). Research is needed to determine whether this unequal sex distribution has remained unchanged because of systematic institutional barriers, personal career choices made by women, or other factors; in order to rectify the underrepresentation of women in academe (particularly at the higher ranks), one must first understand how it has come about.

Let us be clear about what we cannot conclude from our study. Our goals are modest; we do not claim to have addressed all aspects of sex discrimination in one faculty of this university. In the present study, full professors were excluded from the analysis because there were only two female faculty at this rank. Our data do not, of course, allow us to assess why this is the case. Similarly, our study does not enable us to evaluate whether women are discriminated against in the hiring process. Our study does address salary discrimination among assistant and associate professors and discrimination in promotion from assistant to associate professor for those who are at the university.

A number of questions are not neatly answered through regression analysis, or any other statistical procedure. For instance, even selecting which regression models to use (e.g., the decision to include or exclude merit as a predictor) 
might require making assumptions in the absence of supporting evidence (Johnson et al., 1987). These assumptions may lead to increased likelihood of finding or not finding gender discrimination in salary (Birnbaum, 1979; McLaughlin et al., 1983; Ramsey, 1979). Additionally, although it did not happen in the present case study, if the results of different regression models conflict, on what basis does one decide which results to accept?

Even if gender discrimination in salary were clearly demonstrated by the regression analysis, how would one rectify this inequity? Which is the appropriate target - women as a class or individual women? Should all women (even those the regression model indicates are overpaid) receive an amount equal to the average discrepancy? Should only underpaid women ( as specified by the model) have their salary raised by an amount equal to the difference between their predicted and actual salaries? Furthermore, a regression model used to identify salary inequity for women will also identify men who are underpaid. What action, if any, should be taken on their behalf? Finally, what degree of underpayment requires redress? Any underpaid amount? Only actual salaries that are one standard deviation below predicted? Those that are two standard deviations below predicted?

Perhaps we should have only modest goals for regression analyses in resolving salary discrimination disputes. Regression models may be useful to indicate whether a problem exists or not, and even to hint at the extent of the problem. But, the persuasiveness of the statistical case will be influenced by the cohesiveness, trust, and political climate that exist in the academic institution, both between administrators and faculty and between men and women. Of note, our colleagues' reactions to our results ranged from one extreme to the other. On one hand, some accused us of covering up the gender discrimination against women that truly does exist, through our choice of regression models and inclusion of "tainted" predictors. On the other hand, some felt that our failure to find a male-female salary difference demonstrated that men, in fact, were underpaid, since they believed males were indeed more "meritorious" (i.e., more scientifically productive) and this was not taken into account by the regression equation. Clearly, further research is needed to elaborate the role that statistical analyses can play in what is ultimately a political arena (see Dagg \& Thompson, 1988), wherein perceived social reality is just as crucial as the socalled facts. 


\section{Notes}

1 This analysis should be interpreted cautiously since three cells contain fewer than five observations.

\section{References}

Birnbaum, M.H. (1979). Procedures for the detection and correction salary inequities. In T.R. Pezzullo \& B.E. Brittingham (Eds.), Salary equity: Detecting sex bias in salaries among college and university professors. Lexington, Mass.: D.C. Heath and Co., pp. 121-144.

Carter, R.D., Das, R.S., Garnello, A.H., \& Charboneau, R.C. (1984). Multivariate alternatives to regression analysis in the evaluation of salary equity-parity. Research in Higher Education, 20, 167-179.

Dagg, A.I., \& Thompson, P.J. (1988). MisEducation: Women and Canadian universities. Toronto: The Ontario Institute for Studies in Education.

Emmons, C. (1982). A longitudinal study of the careers of a cohort of assistant professors in psychology. American Psychologist, 37, 1228-1238.

Ervin, D., Thomas, B.J., \& Zey-Ferrell, M. (1984). Sex discrimination and rewards in a public comprehensive university. Human Relations, 37, 1005-1028.

Guttmann, M.A.J. (1985). Beginning patterns of psychologists: Post Ph.D. International Journal of Women's Studies, 8, 168-174.

Hollands, J. (1988). Women teaching at Canadian universities. Canadian Social Trends, Summer Issue, 5-7.

Johnson, C.B., Riggs, M.L., \& Downey, R.G. (1987). Fun with numbers: Alternative models for predicting salary levels. Research in Higher Education, 27, 349-362.

Kahn, E.D., \& Robbins, L. (issue Eds.). (1985). Sex discrimination in academe. Journal of Social Issues, 41.

Lassiter, R.L. (1983). The development and use of a faculty salary model for a higher education system. Research in Higher Education, 19, 333-358.

Lott, B. (1985). Devaluation of women's competence. Journal of Social Issues, 4I, 4360.

McLaughlin, G.W., Zirkes, M.B., \& Mahan, B.T. (1983). Multicollinearity and testing questions of sex equity. Research in Higher Education, 19, 277-284.

Morse, P.K. (1979). Detection of sex-related salary discrimination: A demonstration using constructed data. In T.R. Pezzullo \& B.E. Brittingham (Eds.), Salary equity: Detecting sex bias in salaries among college and university professors. Lexington, Mass.: D.C. Heath and Co., pp. 13-18.

Ramsey, G.A. (1979). A generalized regression model for predicting college faculty salaries and estimating sex bias. In T.R. Pezzullo \& B.E. Brittingham (Eds.), Salary equity: Detecting sex bias in salaries among college and university professors. Lexington, Mass.: D.C. Heath and Co., pp. 37-54. 
Pezzullo, T.R., \& Brittingham, B.E. (Eds.) (1979). Salary equity: Detecting sex bias in salaries among college and university professors. Lexington, Mass.: D.C. Heath and $\mathrm{Co}$.

Schau, C.G., \& Heyward, V.H. (1987). Salary equity: Similarities and differences in outcomes from two common prediction models. American Educational Research Journal, 24, 271-286.

Schrank, W.E. (1977). Sex discrimination in faculty salaries: A case study. The Canadian Journal of Economics, 10, 411-433.

Schrank, W.E. (1985). Sex discrimination in faculty salaries at Memorial University : A decade later. Report submitted to the President of Memorial University and the Executive Committee of the Memorial University Faculty Association.

Scott, E.L. (1979). Linear models and the law: Uses and misuses in affirmative action. American Statistical Association Proceedings of the Social Statistics Section. Washington, D.C.: American Statistical Association, pp. 20-26.

Syverson, P.D. (1982). Two decades of doctorates in psychology: A comparison with national trends. American Psychologist, 37, 1203-1212.

Tuckman, B.H. (1979). Salary differences among university faculty and their implications for the future. In T.R. Pezzullo \& B.E. Brittingham (Eds.), Salary equity: Detecting sex bias in salaries among college and university professors. Lexington, Mass.: D.C. Heath and Co., pp. 19-36 